and have shown that material with roughly the same partition properties, and with juvenile hormone activity, is widely spread throughout the animal and plant kingdoms: in the tissues of invertebrates and vertebrates, in higher plants, some bacteria and yeasts.

The material extracted from two of these sources, namely from the excrement of the mealworm, Tenebrio, and from yeast, was examined chemically by Schmialek ${ }^{89}$; tho active principle was isolated and shown to be a mixture of trans-trans-farnesol and its aldehyde farnesal. The question arises whethor the natural juvenile hormone in the insect has any relation to farnesol or is of a totally different nature.

At the present time the answer to this question is not known. Farnosol will certainly reproduce all the morphogenetic and gonadotrophic effects of the juvenile hormone in Rhodnius s0 $^{0}$. It is particularly effective if its stability is inereased by blocking the alcohol end of the molecule in the form of an ether (for example, farnesyl mothyl ether) or as the farnosyl acetone ${ }^{41}$.

In the form of the methyl ether, a 0.06 per cent solution of the active trans-trans isomer is far more effective than the natural extract from cecropia. $1 \cdot 2 \mu \mathrm{g}$ will cause a partial retention of larval characters in Rhodnius-a dose of $5.2 \mu \mathrm{g} / \mathrm{g}$ of body-weight ${ }^{23}$. In Antheraea, 20,000 $\mu \mathrm{g}$ of the natural extract from cecropia will cause a partial retention of pupal characters-a dose of $4,000 \mu \mathrm{g} / \mathrm{g}$ of body-weight ${ }^{42}$.

By repeated partition with methyl alcohol, chromatographic separation on silicic acid columns, followed by the crystallization of impurities, a 'non-crystalline fraction' has been isolated which will produce this samo effect in Antheraea at a dose of $5 \mu \mathrm{g}$, that is, $1 \mu \mathrm{g} / \mathrm{g}$ of bodyweight ${ }^{42}$. Accepting these results at their face value this product is about five times as effoctive as farnesyl mothyl ether in Rhodnius.

Further attempted purification by gas-liquid ehromatography leads to heat destruction of the natural substance, but one fraction isolated in this way had an activity twelve times that of the 'non-crystalline fraction'42. Meyer, Schneiderman and Gilbert ${ }^{43}$ report similar results, showing pyrolytic breakdown of the material in the gas-liquid chromatography column, but with some highly active fractions. Röller, Bjerke and MeShan ${ }^{44}$ have isolated a well-definod active substance which is certainly not farnesol.

The significance of these results is uncertain. Assay methods for material that is exerting its action over a period of many days of development, and which is continuously being broken down in metabolism, have no very precise meaning. (By modifying slightly the means of administering the material I have recently repeated the results on Rhodnius as doscribed here with half the earlier dose, that is, with about $2 \cdot 5 \mu \mathrm{g}$ of the active isomer of farnesyl methyl ether per gram of body-weight.) At the present time farnesol derivatives are the only compounds of known chemical composition with juvenile hormone activity. They woro identified as the substance with juvenile hormone activity in the extracts of noninsect material. They have been found in the extracts of cecropia and other silkmoths. Until other known compounds have boon isolated, I am inclined to hold to the provisional hypothesis that the active group in the juvenilo hormone is indeed the triple isoprene unit of farnesol, and that this exists in the natural hormone in some form that has not yet boon defined.

${ }^{1}$ Wigglesworth, v. B., Quart. J. Micro. Sci., y7, 191 (1934).

${ }^{2}$ Wigglesworth, V. B., Quart. J. Micro. Sci., 79, 91 (1936).

${ }^{3}$ Wigglesworth, V. B., J. Insect Physiol., 2, 73 (1958).

4 Piepho, H., Verh. Dtsch. Zoo. Ges. (Wilhelmshaven), 62 (1951).

'Schaller, F., Bull. Soc. Zoo Fr., 77, 195 (1952).

' Williams, C. M., Biol. Bull., Woods Hole, 121, 572 (1961).

'Staal, G. B., Lintom. Bericht., 25,34 (1965).

'Wigglesworth, V. B., The Physiolngy of Insect Metamorphosis (Cambridge

9 Joly, P. Insectes Sociaux, 3, 17 (1956).

Lees, A. D., Symp. Roy. Entomol. Soc. Lond., 1 (Insect Polymorphism), 68 (1961).

"Kaiser, P., Naturwiss., 42, 303 (1955).

${ }^{12}$ Lüscher, M., Naturwiss., 45, 69 (1958).

${ }^{13}$ Wigglesworth, V. B., J. Embryol. Exp. Morph., 1, 269 (1953).

${ }^{14}$ Wigglesworth, V. B., Symp. Soc. Exp. Biol., 11, 204 (1957).

${ }^{15}$ Beermann, W., Chromosoma, 5, 138 (1952).

${ }^{16}$ Jacob, J., and Monod, J., Cold Spring Harbor Symp. Quant. Biol., 26, 193 (1061).

${ }^{17}$ Wigglesworth, V. B., Nalurwiss, 27,301 (1939).

${ }^{18}$ Lawrence, P., thesis, Univ. Camb. (1965).

${ }^{10}$ Ozeki, K., Sci. Papers Coll. Gen. Educ. Univ. Tokyo, 11, 102 (1961).

${ }^{20}$ Picpho, H., Naturviss., 27, 301 (1939).

"2 Plepho, H., and Meyer, H., Biol, Zbl., 70, 252 (1951).

${ }^{29}$ Gilbert, L. I., and Schneiderman, H. A., Trans. Amer. Micro. Soc., 79, 38 (1960).

${ }^{\text {as }}$ Wigglesworth, V. B., J. Insect Physiol., 9, 105 (1063).

${ }^{24}$ Wigglesworth, V. B., J. Exp. Biol., 32, 485 (1955).

${ }^{25}$ Lockshin, R. A., and Williams, C. M., J. Insect Physiol., 10, 642 (1965).

${ }^{24}$ Piepho, H., Z. Tierpsychol, 7, 424 (1950).

${ }^{27}$ Piepho, H., Böden, E., and Holz, I., Z. Tierpsychol., 17, 261 (1960).

${ }^{28}$ Williams, C. M., Nature, 178, 212 (1956).

${ }^{39}$ Coles, G. C., Nuture, 203, 323 (1964).

an Odhiambo, T. R., thesis, Univ. Cambridge (1965).

${ }^{31}$ Pfeiffer, L. W., J. Exp. Zool., 99, 183 (1045).

${ }^{32}$ Odhiambo, T. R., Nature, 207, 1314 (1965).

${ }^{93}$ Thomsen, E., J. Exp. Biol., 26, 137 (1949).

as Sageesser, H., J. Insect Physiol., 5, 264 (1960). ${ }^{35}$ Novák, V. J. A., Slama, K., and Wenig, K., The Ontogeny of Insects, Sym-
posium in Pragne 1959, 147 (1961).

${ }^{36}$ Wigglesworth, V. B., J. Exp. Biol., 25, 1 (1948).

${ }^{37}$ Stegwee, D., J. Insect Physiol., 10, 97 (1964).

${ }^{38}$ Gilbert, L. I. (unpublished results).

${ }^{39}$ Schmialek, Y., Z. Naturf., 16b, 461 (1961).

40 Wigglesworth, V. B., J. Insect Physiol., 7, 73 (1961).

${ }^{41}$ Schmialek, P., Z. Naturf., 18b, 516 (1963).

${ }^{42}$ Williams, C. M., and Law, J. H., J. Insect Physiol.,11, 569 (1965).

${ }^{43}$ Meyer, A. S., Schneiderman, H. A., and Gilbert, L. I., Nature, 206, 272 (1965). 44 Roller, H., Bjerke, J. S., and McShan, W. H., J. Ins?t Physiol., 11, 1185
(1965).

\title{
OBITUARIES
}

\section{Dr. H. R. Marston, F.R.S.}

Dr. Hedley Rat.ph Marston died in Adelaide on August 25, the day before his sixty-fifth birthday, and the day on which he was to retire from his post of chiof of the Division of Biochemistry and Gonoral Nutrition of the Australian Commonwealth Scientific and Industrial Research Organization. He was one of three brothers born in Bordertown, South Australia; his father was a Civil Servant. The family moved to Adelaide where he attended Unley High School. A school-fellow, Mark (now Sir Mark) Oliphant, attained high seiontific distinction and remained $a$ life-long friend. In 1934 Marston married Kathleon Nelly Spooner, who survives him. They had no children.
There were two rather unusunl features about Marston's career. From first to last he held appointments in Adelaide; and his first degree was conferred on him honoris causa, some thirty-three years after his first academic appointment. When an undergraduate student of chemistry in the University of Adelaide, he chanced to meet, during a country walk, a stranger with whom he fell into conversation. This proved to be Brailsford Robertson, newly arrived to take up the chair of physiology and biochemistry in the University. Within a few days, Marston had joined Robertson's departmont as demonstrator, and during the next seven years assisted him in organizing the teaching of biochemistry and physiology in the University. In 1926, Marston sat for the B.Sc. examination in biochemistry and physiology and headed the honours list; but he was 
by then so fully engaged in research and teaching that he was unwilling to retrace his steps in order to comply with the regulations necessary for taking a degree. This rather unorthodox entry to the academic world in some degree recalls that of Gowland Hopkins, who was first an articled pupil to a public analyst: he moved to Guy's Hospital Modical School, where he took a medical degree, but only in time snatched from research and teaching commitments. It may be that academie life will be the poorer now that insistence on 'paper qualifications' has made such unusual débuts all but impossible. During these early years, Marston received much help from Archibald Watson, the professor of anatomy, of whom he always spoke with affection, as well as from Brailsford Robertson.

His first paper adumbrated the importance of the mitochondria as centres of enzyme activities - a concept since amply confirmed. In other papers he showed for the first time that the mammary gland of the monotreme echidna did indeed secrete true milk, described the first micromethod for the determination of guanidine and methyl guanidine, and published work on the sterol isolated from the 'giant toad stool'.

In 1927 he joined the Division of Animal Nutrition of the (then) C.S.I.R., newly formed under Brailsford Robertson. He was in charge of the Division between Robertson's death in 1929, and the appointment of Sir Charles Martin as chief in 1930. A close bond grew up with Martin, and when he returned to England in 1932, Marston was appointed chief nutrition officer, and placed in charge of the Nutrition Laboratory, which became part of the Division of Animal Health until 1944, when the Division of Biochemistry and General Nutrition was established with Marston as its first chief. During this period the researches of Marston and his colleagues covered a wide field and had important practical applications. While he always insisted that advances in practice depended on an understanding of the underlying natural phenomena, he nevertheless tried to ensure that the practical means of applying scientific principles were available. Among other subjects, the work included valuable fundamental researches on the animal's requirements for protein for the manufacture of skin and wool and on the special need for sulphur-containing amino-acids (now, but not then, common knowledge). He early observed the effect of copper on keratinization and hence on the quality of wool. Other work dealt with the requirements of the sheep for phosphorus, and of the effects on it of thyroidectomy.

In 1936 he was invited by Hopkins to spend a year in the Biochemical Laboratory, University of Cambridge. There he continued his work on carbohydrate fermentation by ruminal micro-organisms, and interested Joseph Barcroft in general problems of ruminal function, with most fruitful results.

During the Second World War he furnished, with his colleagues, valuable information to the Army on available human rations, and compiled highly useful dietary tables. After the War he worked on the basic problems of energy transactions in ruminants. The work for which he is most widely known can be traced to its beginnings in 1933, when he became interested in 'Coast disease'. Considerable stretches of land, among them the 'ninety mile desert' near his birthplace, would support neither useful erops nor domestic stock. This was (wrongly) ascribed to phosphorus deficiency. Marston and his colleagues showed that phosphorus was adequate, but that there was a lack of cobalt and copper, and in certain areas of zinc, and that traces of such elements would permit the normal growth of both plants and animals. These fundamental discoveries proved the key to the solution of difficulties encountered by agriculturists and pastoralists in other continents besides Australia, and gave impetus to the conception of the importance of heavy metals in biological processes which is still growing. Marston was able to show that cobalt was effective only after it had been incorporated into vitamin $B_{12}$ by ruminal micro-organisms, and that at least one of its functions in the body was that of co-enzyme in certain isomeric changes. The story must now be left to other hands to unfold: that there are further chapters is certain.

Marston was widely read, and widely travelled, both in Europe and the United States, with a fund of reminiscences of people and places. In 1957 he was elected D.Se. honoris causa (his first degree) by the Australian National University, and in $\mathbf{1 9 5 9}$ to a D.Sc. of the University of Adelaide ad eundem gradum. He was invited to lecture on the work of the Division to the Royal Society of London in 1948, and was elected Fellow in 1949. In 1951, Sir Mark Oliphant and he were active in the foundation of the Australian Academy of Sciences, of which they were original members. He numbered among his close friends not only scientific colleagues such as Martin, Hopkins, Rivett, Oliphant and E. V. MeCollum, but also famous artists, and leaders in the industrial world such as W. S. Robinson in Australia and J. L. Pratt and Robert Kleberg, jun., in the United States. Perhaps from such contacts sprang some of his sympathy with practical problems.

E. G. Holmes

\section{Prof. Arthur Holmes, F.R.S.}

Arthur Holmes, emeritus professor of geology and mineralogy in the University of Edinburgh, died on September 20 at the age of seventy-five at his home in Putney. His brilliant research on the wider problems of geology has earned him his place as one of the great Earth scientists of the century.

Holmes was born at Hebburn, near Newcastle-uponTyne, in 1890. He graduated at the Imperial College of Science and Technology in 1910 and undertook an expedition to Mozambique in 1911. Here an attack of blackwater fever nearly ended his career (there was in fact an announcement of his death in the local paper), but he came back to rejoin the staff of Imperial College until 1921. He then joined the Yomah Oil Co. in Burma as chief geologist; but, fortunately for the future of geological science, he returned in 1924 to become head of the newly created Department of Geology in the University of Durham, which under his leadership rapidly gained an international reputation for petrological rosearch. In 1943 he was appointed regius professor of geology in the University of Edinburgh, which was honoured with his occupation of the chair for thirteen years, and with his presence as emeritus professor for six years after he retired in 1956 .

Prof. Holmes has exercised a profound influence on almost all branches of geology, not only through his own remarkable researches but also by his beautifully written text-books and the stimulation of the research qualities of his students. His output of publications has been prodigious-nearly 200 , including several famous text-books such as The Age of the Earth, Nomenclature of Petrology, Petrographic Methods and Calculations and Principles of Physical Geology. He has made a great number of contributions to our knowledge of the geology of many parts of the world, from his home district in the north of England to Africa, India and elsewhere; but the descriptive aspect of his work has been, far more than with most men, merely a prelude to his remarkable work on the wider genetic problems of the seience. He went deeply into the major questions of the origin of igneous rocks, partly in association with his accomplished and eminent wife, Dr. Doris Reynolds. He was never a man to shun controversy, and his work on the origin of the alkaline rocks of Africa and elsewhere, on the thorny problems of granites and their associates, on the origin and development of magmas, and on the role of metasomatism in rock genesis, has broadened the vision of igneous and metamorphic petrologists all over the world.

During his school-days, Holmes's inquiring mind had questioned the magic date for the Creation, 4004 B.C., in Archbishop Ussher's chronology for the book of Genesis, 